\title{
DAMPAK FERTILITAS TERHADAP KEBUTUHAN DASAR KELUARGA \\ (Studi Kasus Pada Keluarga Dengan Jumlah Anak Lebih Dari Dua \\ di Desa Pondok Kelapa, Kabupaten Bengkulu Tengah)
}

\author{
Heri Sunaryanto \\ Dosen Jurusan Sosiologi FISIP Universitas Bengkulu
}

\begin{abstract}
The aim of this study was to analyze the impact of high fertility on the fulfillment of basic needs in Central Bengkulu Regency. This research is quantitative descriptive with the number of respondents was 50 people. The analytical method used was SPSS (Statistic Program for Sosial Sciences) with cross tabulation analysis and triangulation. The results showed that there was no relationship between the number of children and the fulfillment of basic needs such as education, fulfillment of food, shelter and health. There are several reasons of the explanation of the social reality. Furthermore, from the people perspective high fertility level is more linked to social values of children than of the calculation based on the fulfillment of basic needs.
\end{abstract}

Keywords: Impact Fertility, Education, Housing, Food and Health.

\section{PENDAHULUAN}

Dalam kajian kependudukan di negara berkembang, fertilitas menjadi determinan faktor yang lebih berpengaruh dibandingkan faktor lain terhadap laju pertumbuhan penduduk (Todaro dan Smith, 2009:297). Sebagaimana diketahui bahwa laju pertumbuhan penduduk dipengaruhi oleh fertilitas, mortalitas dan migrasi. Pentingnya fertilitas telah menghasilkan berbagai kajian dan riset dari berbagai perspektif yang mencoba menjelaskan dan menjawab tentang tingginya angka fertilitas di sebuah daerah. Lebih jauh dari berbagai kajian fertilitas, domain fertilitas begitu luas yang secara langsung maupun tidak langsung berhubungan erat dengan berbagai dimensi baik politik, ekonomi, sosial dan budaya (Hagedorn, 1990 : Todaro dan Smith, 2009 : Adioetomo, 2010). Keadaan ini telah menjadikan fertilitas sebagai variabel yang rumit (complicated) dibandingkan dengan variabel kependudukan lainnya yaitu mortalitas dan migrasi.

Sejauh ini kajian fertilitas lebih difokuskan kepada berbagai determinan yang berpengaruh terhadap tingginya 
angka fertilitas baik dari perspektif makro maupun mikro. Secara makro, misalnya Todaro dan Smith (2009) dalam bukunya Economic Development in Third World Countries menjelaskan hubungan pertumbuhan ekonomi suatu negara dengan angka kelahiran dan laju pertumbuhan penduduk dengan melakukan kajian fertilitas di beberapa negara maju dan negara berkembang. Dari perspektif mikro, begitu banyak kajian yang menjelaskan berbagai faktor sosial ekonomi yang berpengaruh terhadap tinggi dan rendahnya fertilitas (Davis and Blake, 1956; Hugo et.al.,1997; United Nation, 2001, Adioetomo, 2010).

Akan tetapi, sedikit kajian yang menjelaskan pengaruh fertilitas terhadap aspek sosial-eknomi masyarakat baik secara makro maupun mikro. Banyak kajian yang menjelaskan pengaruh kemiskinan dengan tinggi atau rendahnya angka fertilitas sebuah keluarga. Tetapi sedikit kajian yang menjelaskan tingginya angka fertilitas terhadap kemiskinan. Memang secara mikro, dibandingkan dengan faktorfaktor yang mempengaruhi fertilitas (dependent variable), fertilitas sebagai variabel independen lebih terbatas. Tentu saja keterbatasan ini bukan berarti bahwa kajian dampak fertilitas menjadi tidak penting. Justru sebaliknya, perlu kajian yang komprehensif dari berbagai dimensi terhadap dampak tingginya fertilitas.

Secara metodologi keadaan ini memang rancu dalam pengertian bahwa variabel kemiskinan atau fertilitas yang menjadi variabel independen artinya kemiskinan yang mempengaruhi fertilitas atau sebaliknya fertilitas yang berpengaruh terhadap kemiskinan. Secara logika, dapat dipahami bahwa fertilitas tinggi berdampak pada biaya yang tinggi guna memenuhi kebutuhan hidup sebuah keluarga. Dari perspektif ekonomi fertilitas bahwa anak dapat dianggap sebagai aset tetapi juga dapat dianggap sebagai beban keluarga tergantung bagaimana keluarga melihat nilai anak. Yang pasti bahwa setiap keluarga umumnya mendambakan anak, karena anak adalah harapan atau cita-cita dari sebuah perkawinan. Berapa jumlah anak yang diinginkan, tergantung dari keluarga itu sendiri. Apakah ingin memiliki satu, dua, tiga dan seterusnya. Keputusan untuk memiliki jumlah anak adalah sebuah pilihan, yang mana pilihan tersebut sangat dipengaruhi oleh nilai yang dianggap sebagai suatu harapan atas setiap keinginan yang 
dipilih oleh orang tua (Adi oetomo, 2010). Ekonomi kependudukan mikro menjelaskan bahwa dari sudut pandang orang tua atau dari satuan keluarga menganggap anak sebagai barang konsumsi tahan lama atau barang mewah, yaitu dapat memberikan kepuasan dalam waktu yang lama (Todaro dan Smith, 2009: 313).

Kajian ini merupakan salah satu studi yang mencoba menemukan jawaban terhadap dampak fertilitas terhadap kondisi ekonomi keluarga. Kajian ini sekaligus mencoba mencari penjelasan yang komprehensif bahwa upaya pengendalian penduduk dengan fokus utamanya adalah penurunan fertilitas bukan semata untuk penurunan laju pertumbuhan penduduk Indonesia yang masih relatif tinggi, akan tetapi jauh dibalik itu adalah upaya penanggulangan kemiskinan dan penguatan ekonomi keluarga Indonesia.

Dari penjelasan sebelumnya bahwa permasalahan fertilitas tidak hanya sebagai variabel dependen, tetapi fertilitas juga dapat menjadi variabel independen. Secara logika, jumlah anak yang dimiliki keluarga akan berdampak secara signifikan dengan upaya pemenuhan kebutuhan dasar (basic needs) keluarga. Dengan demikian, penelitian ini bertujuan untuk (1). mengetahui dan menganalisa pandangan keluarga terhadap nilai sosial-ekonomi anak dan (2). Menganalisa dampak fertilitas terhadap kebutuhan dasar keluarga.

\section{METODE PENELITIAN}

Penelitian ini merupakan penelitian kuantitatif deskriptif dimaksudkan memberi analisis dampak fertilitas terhadap kemampuan keluarga dalam memenuhi kebutuhan dasar. Data yang digunakan adalah data primer dan sekunder. Data primer diperoleh langsung dari lapangan melalui daftar pertanyaan terstruktur (constructed questioner) terhadap 50 responden terpilih ( memiliki anak lebih dari 2 orang) di desa Pondok Kelapa, Kecamatan Pondok Kelapa, Kabupaten Bengkulu Tengah. Teknik sampel yang digunakan adalah multistage random sampling berbasis wilayah administrasi. Dari provinsi diturunkan ke kabupaten, kecamatan, desa dengan beberapa pertimbangan. Selanjutnya data diolah dengan menggunakan SPSS (Statistic Program for Sosial Sciences) yang selanjutnya dipresentasikan dalam bentuk tabel frekuensi dan crosstabulation antar variabel. Interpretasi dan analisis terhadap data dan informasi 
dilakukan dengan teknik trianggulasi yaitu dengan melakukan cross check dengan teori yang ada dan hasil penelitian sejenis yang dilakukan ditempat lain. Hal demikian dilakukan untuk mencapai derajat obyektifitas sebagaimana dipersyaratkan layaknya kajian keilmuan (Bungin, 2010). Sedangkan data sekunder adalah hasil publikasi dari Badan Statistik Nasional (Sensus Penduduk, Survey Antar Sensus (SUPAS), Survey Sosial-Ekonomi Nasional (SUSENAS), data hasil SDKI yang dipublikasikan dan data-data dari hasil mini survei dan pendataan keluarga yang dilakukan olek BKKBN, data dari studi-studi yang dilakukan oleh Pusat Studi Kebijakan dan Kependudukan Universitas Bengkulu, juga data hasil studi lembaga lain yang terkait dengan permasalahan penelitian.

\section{HASIL DAN PEMBAHASAN}

\section{Perspektif Dampak Fertilitas}

Kajian dampak fertilitas terhadap ekonomi keluarga menurut beberapa ahli lebih diorientasikan perilaku fertilitas pada masyarakat yang lebih maju (industri) dimana ekonomi material menjadi orientasi hidup individu (Goldscheider, 1985). Artinya bahwa modernisasi telah menyebabkan terjadinya transformasi struktual yaitu pergeseran peran keluarga (domestik) menjadi peran yang diambil alih institusi publik. Peran kekerabatan (extended family) sebagai pusat pendidikan, ekonomi dan politik diambil alih oleh lembaga-lembaga formal dan nonformal. Perubahan ini lebih jauh telah menyebabkan penurunan fertilitas di negara-negara maju karena struktur lembaga ekonominya telah berubah, yang berpengaruh terhadap standar hidup yang tinggi, aspirasi untuk mobilitas dan keuntungan-keuntungan ekonomi dan sosial yang bersifat nonkeluarga. Anak tidak dilihat dalam kemanfaatan secara sosial tetapi lebih diangap beban ekonomi karena biaya ( cost) yang harus ditanggung berbanding lurus dengan jumlah anak yang dimiliki. Biaya yang dimaksud adalah biaya yang harus diberikan kepada lembagalembaga formal seperti pendidikan, kesehatan, pemenuhan kebutuhan hidup, peningkatan gizi keluarga, dan seterusnya (Goldschider, 1985: 221226). Sebagaimana yang disinyalir oleh Todaro (2009:326) keluarga besar dan pendapatan yang rendah mempersempit peluang orang tua untuk menyekolahkan anak-anak mereka dan memenuhi kebutuhan pangan mereka. Selanjutnya 
upaya-upaya untuk memenuhi kebutuhan tersebut telah menyebabkan keluarga tidak memiliki kemampuan untuk menyimpan uangnya (private saving).

Namun demikian, pada masyarakat tertentu hubungan fertilitas dengan beban keluarga tidak dipandang sebagai bentuk hubungan yang erat. Dalam pengertian bahwa dalam derajat tertentu persoalan jumlah anak tidak dikaitkan dengan dengan tingkat kemampuan ekonomi atau aspek sosial lainnya. Dalam perspektif sosiologi fertilitas, tingkat fertilitas dipengaruhi oleh norma-norma yang dianut oleh masyarakat yaitu norma tentang besarnya keluarga (Freedman, 1962). Weber (dalam Ritzer, 2005) menegaskan bahwa perilaku sosial merupakan refleksi pikiran seseorang hasil interaksi dengan nilai-nilai sosial kultural yang menjadi medianya. Memiliki anak adalah salah satu tujuan perkawinan atau pembentukan keluarga. Artinya setiap pasangan perkawinan dipastikan ingin memiliki anak. Ekspektasi terhadap berapa jumlah minimal anak yang diinginkan merupakan domain budaya. Karena budaya merupakan perilaku subyektif kelompok, maka besarnya jumlah anak akan berbeda antar masyarakat pada budaya yang berbeda
(Becker, 1981). Seperti dijelaskan oleh Goldscheider (1985) bahwa fertilitas berbeda dengan mortalitas, erat sekali hubungannya dengan norma-norma khusus tentang besarnya keluarga. Beberapa pakar kependudukan sepakat bahwa melembaganya fertilitas yang tinggi pada masyarakat pra modern lebih disebabkan oleh sistem nilai budaya yang pronatalis (Davis and Blake 1955, Freedman, 1954).

Pada situasi dimana nilai-nilai budaya (cultural factors) sebagaimana digambarkan oleh Becker dan Goldscheider menjadi faktor utama dalam mempengaruhi banyak atau sedikitnya jumlah anak yang dimiliki keluarga, maka dampak fertilitas terhadap kondisi sosial-ekonomi keluarga menjadi tidak signifikan. Artinya, pada situasi seperti ini, orientasi keluarga miskin atau kaya terhadap jumlah anak yang diinginkan relatif tidak ada perbedaan. Menilai anak dari perspektif beban atau aset sebagai disampaikan oleh teori ekonomi fertilitas menjadi tidak pas untuk menjelaskan fenomena perilaku fertilitas keluarga. Kajian data SDKI 2007 dan Sensus 2010 tentang fertilitas penduduk di provinsi Bengkulu oleh PSKK Universitas Bengkulu (Sunaryanto, 2010, 2011) 
menunjukkan bahwa faktor-faktor sosialekonomi seperti pendidikan, domisili, pekerjaan, dan pendapatan tidak memiliki hubungan dengan perilaku fertilitas sebagaimana telah diteorisasikan oleh banyak ahli selama ini.

\section{Dampak Fertilitas}

Sub bab ini membahas hasil olah data menggunakan SPSS terkait dengan dampak jumlah anak terhadap upaya keluarga dalam memenuhi kebutuhan minimum dasar seperti perumahan, ketahanan pangan, kesehatan dan pendidikan yang selanjutnya digunakan untuk justifikasi tingkat kemiskinan keluarga. Mengukur pemenuhan kebutuhan dasar tersebut (tingkat kemiskinan) bukan hal yang mudah mengingat banyak paramater yang dapat digunakan dan tidak menutup kemungkinan saling kontradiksi disamping saling menguatkan (Cahyat, 2004). Sebagaimana disampaikan oleh Suparlan (1993:10) bahwa dalam ilmu sosial pemahaman mengenai pengertian kemiskinan dilakukan dengan menggunakan tolak ukur tertentu. Adapun tolak ukur yang pertama adalah tingkat pendapatan per waktu kerja, dengan adanya tolak ukur ini maka jumlah dan siapa-siapa saja yang tergolong sebagai orang miskin dapat diketahui, untuk dijadikan sebagai kelompok sasaran yang diperangi kemiskinannya. Tolak ukur yang kedua adalah tolak ukur kebutuhan relatif perkeluarga yang batasannya dibuat berdasarkan kebutuhan minimal yang harus dipenuhi sebuah keluarga agar dapat melangsungkan kehidupannya secara sederhana tetapi memadai sebagai warga masyarakat yang layak. Tercakup dalam tolak ukur kebutuhan relatif per keluarga ini adalah : kebutuhankebutuhan yang berkenan dengan biaya sewa rumah, biaya-biaya untuk memelihara kesehatan dan untuk pengobatan, biaya-biaya untuk menyekolahkan anak-anak, dan biaya untuk sandang yang sewajarnya dan pangan yang sederhana tetapi mencukupi dan memadai (Coudouel, 2002).

Sebagaimana diteorisasikan pada pembahasan sebelumnya bahwa jumlah anak merupakan vaiabel tidak langsung yang berhubungan dengan kemampuan keluarga untuk memenuhi kebutuhan dasar untuk kelangsungan kehidupannya. Dalam beberapa kajian sering kali jumlah anak ini dikaitkan dengan beban keluarga dan di lapangan faktanya menjadi tidak sederhana karena 
parameter yang digunakan oleh sebuah keluarga untuk menilai atau menjelaskan apakah anak menjadi beban atau tidak bagi keluarga menjadi sangat luas dimensinya. Sistematika pembahasan pada bab ini akan dimulai dengan melihat jawaban responden terhadap nilai anak bagi keluarga dan selanjutnya secara komprehensif dikaitkan dengan aspek kebutuhan dasar sehingga akan diperoleh gambaran yang utuh guna menjawab hubungan jumlah anak dengan upaya pemenuhan kebutuhan dasar keluarga.

\section{Nilai anak}

Studi perilaku fertilitas penduduk menampilkan dua mainstream besar terkait dengan ekpektasi terhadap jumlah anak yang diinginkan dalam keluarga dimana ekspektasi ini terkait dengan pemaknaan anak bagi kepentingan dan kebutuhan keluarga yang sering disebut dengan nilai anak (value of children). Nilai anak memiliki dimensi pemaknaan yang luas baik secara sosial, budaya maupun ekonomi. Secara sosio-kultural anak dapat dimaknai sebagai, penerus keturunan, aset, jaminan masa depan, harapan perubahan nasib dan pembantu ekonomi keluarga (Todaro dan Smith, 2003, Adioetomo dkk, 2010).
Pemaknaan terhadap anak bagi keluarga inilah menjadi faktor terpenting terkait dengan dampak fertilitas terhadap kondisi keluarga.

Secara makro ada dua sudut pandang melihat nilai anak, satu sisi melihat anak sebagai beban keluarga sedang pandangan yang lain melihat anak sebagai aset keluarga. Kedua pandangan ini sangat dipengaruhi oleh nilai-nilai sosial-budaya yang diapresiasi seseorang melalui proses sosialisasi yang dialami. Dengan mempertimbangkan aspek sosio-kultural, maka apakah anak menjadi beban atau aset menjadi sisi obyektif-subyektif si individu dan tentu saja menjadi sesuatu yang relatif yang tidah mudah untuk dijelaskan. Masalah seperti ini juga sama persis dengan apa yang dijelaskan oleh Adioetomo (2010) merujuk pada berbagai studi di Indonesia tentang besar atau kecilnya jumlah anak bagi keluarga dan jumlah anak yang dianggap ideal dalam suatu keluarga. Dari berbagai studi di Jawa menunjukkan bahwa masing-masing daerah memiliki persepsi yang berbeda berkaitan dengan berapa anak dalam keluarga disebut banyak atau sedikit demikian juga terhadap jumlah ideal anak dalam keluarga. Ada individu yang mengatakan 6 orang sedikit tapi juga ada 
yang mengatakan 6 orang termasuk banyak. Sedangkan jumlah ideal anak dalam keluarga dapat disimpulkan antara 4-6 anak (Adioetomo, 2010: 55-67).

Tabel 1 Mendeskripsikan proporsi tentang nilai anak bagi keluarga di daerah penelitian. Dari 50 responden, 24 persen dari mereka menyatakan anak menjadi beban dan mayoritas (76 persen) menganggap anak tidak menjadi beban keluarga. Perlu dijelaskan disini bahwa anak menjadi beban atau tidak menjadi beban keluarga, ini persepsi yang relatif sebagaimana telah dijelaskan sebelumnya. Domain ini sangat dipengaruhi oleh latar belakang sosial- budaya dan parameter subyektif responden. Artinya, setiap individu memiliki sudut pandang yang bisa saja berbeda dari mulai aspek psikologis, sosiologis dan ekonomi. Apa yang dikatakan beban bagi seseorang belum tentu dirasakan menjadi beban bagi individu yang lainnya karena beda cara menilainya. Untuk menjelaskan hal-hal seperti ini diperlukan kajian kualitatif yang komprehensif sehingga dapat ditemukan pola jawaban dan pemahaman yang sesungguhnya terhadap konsep tersebut (beban/tidak beban).

Tabel 1 Distribusi Frekuensi Nilai Anak Bagi Keluarga, 2012

\begin{tabular}{|c|c|c|}
\hline Beban & Frequency & Percent (\%) \\
\hline Ya & 12 & 24 \\
\hline Tidak & 38 & 76 \\
\hline Total & $\mathbf{5 0}$ & $\mathbf{1 0 0}$ \\
\hline
\end{tabular}

Sumber : Data Primer, 2012

Tabel 1 memberi penjelasan bahwa dari mereka yang menganggap anak menjadi beban keluarga (12 keluarga), 66 persen dari mereka tergolong berpenghasilan rendah. Akan tetapi mereka yang menganggap anak bukan menjadi beban (38 keluarga), 65,7 persen juga berasal dari kalangan dengan berpendapatan rendah.

Sungguh fenomena ini kontradiksi dengan teori yang dibangun oleh beberapa pakar, sebut saja Todaro (2003) bahwa hubungan pendapatan dengan upaya keluarga memenuhi kebutuhan anak merupakan hubungan yang sangat kuat sebagaimana dijelaskan dalam teori mikro ekonomi fertilitas rumah tangga. Secara ringkas teori ini mejelaskan bahwa jumlah anak yang 
diinginkan akan dipengaruhi secara langsung oleh pendapatan keluarga. Karena secara ekonomi jumlah anak berhubungan dengan beban yang harus ditanggung keluarga. Artinya semakin tinggi pendapatan keluarga, akan semakin besar pula permintaan akan anak (Todaro dan Smith, 2003:313-314). Pada Tabel 2 ditunjukkan bahwa 33 keluarga dari 50 keluarga terpilih atau 66 persen berpenghasilan terkategori rendah yaitu dibawah 1 juta per bulan.

Tabel 2 Distribusi Frekuensi Nilai Anak urut Pendapatan Keluarga

\begin{tabular}{|l|c|c|c|c|}
\hline \multirow{2}{*}{ Beban } & \multicolumn{3}{|c|}{ Pendapatan } & \multirow{2}{*}{ Total } \\
\cline { 2 - 5 } & Rendah & Sedang & Tinggi & $12(100)$ \\
\hline Ya & $8(66,6)$ & $4(33,4)$ & - & $38(100)$ \\
\hline Tidak & $25(65,7)$ & $6(15,7)$ & $7(18,6)$ & $\mathbf{5 0}$ \\
\hline Total & $\mathbf{3 3}$ & $\mathbf{1 0}$ & $\mathbf{7}$ & $\mathbf{5}$ \\
\hline
\end{tabular}

Sumber : Data Primer, 2012

\section{Dampak Terhadap Tempat Tinggal}

Tempat tinggal apakah status kepemilikan ataupun jenis bangunan sering dijadikan parameter untuk mengukur tingkat kesejahteraan penduduk. Secara sosiologis orang dikatakan sejahtera kalau memiliki rumah sendiri, besar dan bagus atau sebaliknya orang yang tidak memiliki rumah dianggap belum sejahtera. Pada masyarakat modern perkotaan, memiliki rumah merupakan aset yang sangat berharga karena harganya yang mahal. Tumbuhnya komplek perumahan mewah disamping menjadi simbol kemapanan sekaligus menjadi pembeda status sosial dan tidak jarang menjadi sumber konflik antar klas sosial (John Rex dalam Gillis, 1990: 501-503). Informasi yang diperoleh di lapangan menunjukkan bahwa 94 persen keluarga yang terpilih menjadi responden memiliki rumah sendiri dan hanya 10 persen yang bangunan rumahnya terbuat dari papan. Dari mereka yang memiliki rumah sendiri (47 orang), 30 orang $(66,8$ persen) berpenghasilan rendah. Artinya mayoritas mereka tidak memiliki masalah dengan tempat tinggal dan fenomena ini juga menjelaskan bahwa pendapatan keluarga dan kepemilikan rumah tidak memiliki hubungan yang signifikan.

Selanjutnya untuk mengetahui dampak jumlah anak terhadap kemampuan keluarga menyediakan tempat tinggal yang standar, studi ini menggunakan luas bangunan sebagai 
parameter. Dari perspektif kesehatan, rumah yang sempit dan sumpek akan berdampak pada kondisi kesehatan penghuninya. Menurut pandangan kesehatan bahwa setiap orang membutuhkan 8 meter persegi $\left(\mathrm{m}^{2}\right)$ untuk dapat disebut memiliki ruang yang lapang dan sehat. Sehingga dengan ukuran 2 anak dalam satu keluarga sebagaimana yang diinginkan oleh negara (Keluarga Berencana), maka minimal keluarga tersebut harus memiliki luas tempat tinggal sekitar 32 meter persegi $\left(\mathrm{m}^{2}\right)$. Untuk kepentingan penelitian ini maka 32 meter persegi dijadikan standar parameter untuk menilai kelayakan tempat tinggal responden. Tabel 3 mendeskripsikan hubungan jumlah anak dengan luas rumah yang ditempati. Data menunjukkan bahwa 37 (74 persen) dari 50 keluarga terpilih memiliki rumah dengan luas bangunan yang memenuhi standard kesehatan yaitu $32 \mathrm{~m}^{2}$ lebih dan mayoritas mereka (62 persen) hanya memiliki anak 3 orang saja. Artinya bahwa dari sisi tempat tinggal mereka mampu menyediakan rumah yang memenuhi standar kesehatan dilihat dari aspek ruang (space). Oleh karena itu dikaitkan dengan pembahasan sebelumnya tentang nilai anak, tidak mengherankan apabila mayoritas mereka menjawab jumlah anak yang dimiliki tidak menjadi beban.

Tabel 3 Luas Bangunan Rumah Menurut Jumlah Anak

\begin{tabular}{|c|c|c|c|c|c|}
\hline \multirow{2}{*}{$\begin{array}{c}\text { Jumlah } \\
\text { Anak }\end{array}$} & \multicolumn{4}{|c|}{ Luas Bangunan } & \multirow{2}{*}{ Total } \\
\cline { 2 - 5 } & \multicolumn{2}{|c|}{$<=31$} & \multicolumn{2}{|c|}{$32=>$} & \\
\cline { 2 - 5 } & Jml & \% & Jml & \% & \\
\hline 3 & 8 & 61,5 & 23 & 62,2 & 31 \\
\hline 4 & 2 & 15,4 & 4 & 10,8 & 6 \\
\hline 5 & 1 & 7,7 & 8 & 21,6 & 9 \\
\hline 6 & 2 & 15,4 & 2 & 5,4 & 4 \\
\hline Total & $\mathbf{1 3}$ & $\mathbf{1 0 0}$ & $\mathbf{3 7}$ & $\mathbf{1 0 0}$ & $\mathbf{5 0}$ \\
\hline
\end{tabular}

Sumber : Data Primer, 2012.

Dampak Terhadap Pemenuhan Makan

Pemenuhan keluarga dalam mencukupi kebutuhan pangan (beras) telah dijadikan salah satu indikator apakah keluarga tersebut tergolong miskin atau tidak. Sebagaimana telah dijelaskan sebelumnya bahwa kebutuhan 
pangan merupakan salah satu kebutuhan dasar (basic needs). Secara teoritik bahwa jumlah anggota keluarga atau ukuran keluarga juga mempengaruhi pola konsumsi. Hasil Survei Biaya Hidup (SBH) tahun 1989 membuktikan bahwa semakin besar jumlah anggota keluarga semakin besar proporsi pengeluaran keluarga untuk makanan dari pada untuk bukan makanan. Ini berarti semakin kecil jumlah anggota keluarga, semakin kecil pula bagian pendapatan untuk kebutuhan makanan (Sumarwan, 1993). Selebihnya, keluarga akan mengalokasikan sisa pendapatannya untuk konsumsi bukan makanan. Dengan demikian, keluarga dengan jumlah anggota sedikit relatif lebih sejahtera dari keluarga dengan jumlah anggota besar. Oleh karena itu sering dikaitkan antara besarnya jumlah keluarga dan tingkat kemiskinan.

Seperti BPS mengartikan kemiskinan sebagai ketidakmampuan untuk memenuhi standar minimum kebutuhan dasar yang meliputi kebutuhan makanan maupun nonmakanan. Dari sisi makanan, BPS menggunakan indikator yang direkomendasikan oleh Widyakarya Pangan dan Gizi tahun 1998 yaitu 2.100 kalori per orang per hari (Todaro dan Smith, 2003). Sedangkan menurut Menteri Pertanian Yuswono menggunakan tingkat konsumsi ekuivalen beras per kapita sebagai indikator kemiskinan. Menurut Yuswono bahwa kebutuhan konsumsi beras untuk setiap orang per hari sebesar 275 gram. Hal ini berbeda dengan apa yang disampaikan oleh Prof. Sumarno (2006) dari Puslitbang Tanaman Pangan yang menjelaskan bahwa konsumsi beras untuk setiap orang sekitar 370 gram. Dengan menggunakan kedua pendapat di atas, maka kebutuhan konsusmsi beras setiap orang dalam satu minggu (7 hari) berkisar antara $1,9 \mathrm{Kg}$ sampai 2,5 $\mathrm{Kg}$ beras. Dengan menggunakan standar konsumsi beras tersebut, maka kebutuhan beras setiap bulan akan berbeda antar keluarga tergantung dengan jumlah anggota keluarga yang menjadi tanggungan keluarga. Keluarga dengan jumlah anak banyak secara otomatis akan mengkonsumsi beras lebih banyak. Berangkat dari asumsi seperti inilah maka fertilitas mempunyai dampak yang signifikan terhadap upaya pemenuhan konsumsi beras bagi keluarga. 
Tabel 4 Proporsi Kebutuhan Konsumsi Makan Keluarga, 2012

\begin{tabular}{|l|c|c|}
\hline \multicolumn{1}{|c|}{ Konsumsi Pangan } & Jumlah & Persen \\
\hline Konsumsi Beras Per-Minggu & & \\
Baik ( $\geq$ 2 Kg/orang/Hari) & 30 & 60 \\
Kurang baik (<2 Kg/orang/Hari) & 20 & 40 \\
Total & $\mathbf{5 0}$ & $\mathbf{1 0 0}$ \\
\hline Makan nasi dalam sehari & & \\
2x & 10 & 20 \\
3x dan lebih & 40 & 80 \\
Total & $\mathbf{5 0}$ & $\mathbf{1 0 0}$ \\
& & \\
\hline Menu makan hari ini & & \\
Nasi & 1 & 2 \\
Nasi dan Sayur & 9 & 18 \\
Nasi dan Lauk & 16 & 32 \\
Nasi, Sayur, dan lauk & 24 & 48 \\
Total & $\mathbf{5 0}$ & $\mathbf{1 0 0}$ \\
\hline
\end{tabular}

Sumber : Data Primer, 2012.

Tabel 4 mendeskripsikan tingkat konsusmsi beras setiap keluarga dan pola pemenuhan makan setiap hari. Menggunakan ukuran minimum sebagaimana disampaikan oleh Menteri Pertanian bahwa minimal seseorang mengkonsumsi beras sebanyak 275 gram setiap hari, maka dari 50 keluarga, 60 persen dapat memenuhi kebutuhan beras setiap harinya dan 40 persen masih tergolong miskin. Lebih jauh dengan menggunakan standar BKKBN untuk Keluarga Sejahtera satu (Keluarga Miskin), dimana salah satu indikator ekonomi adalah paling kurang sekali seminggu keluarga makan daging atau ikan atau telor (Cahyat, 2004), maka 80 persen keluarga terpilih setiap harinya sering makan 3 kali dan 66 persen atau
33 keluarga makan dengan kombinasi nasi plus lauk dan atau sayur. Dilihat dari perspektif ini sebenarnya mayoritas mereka tidak tergolong keluarga miskin meskipun jumlah anak mereka lebih dari 2 orang. Oleh karena itu pada studi ini dapat dikatakan bahwa jumlah anak banyak tidak berdampak pada sulitnya upaya pemenuhan kebutuhan makan minimum keluarga sesuai dengan parameter yang telah disepakati.

\section{Dampak Terhadap Kesehatan}

Dalam pengukuran Indeks Pembangunan Manusia (IPM), kesehatan adalah salah satu komponen utama selain pendidikan dan pendapatan. Kesehatan juga merupakan investasi untuk mendukung pembangunan ekonomi serta 
memiliki peran penting dalam upaya miskin terutama disebabkan oleh penanggulangan kemiskinan. terbatasnya akses terhadap pelayanan Kemiskinan sering diidentikkan dengan dengan rendahnya derajat kesehatan seseorang. Dalam berbagai studi terkait dengan kesehatan masyarakat bahwa derajat kesehatan seseorang dipengaruhi oleh banyak faktor baik ekonomi, sosial budaya, maupun fasilitas kesehatan. kesehatan karena kendala geografis dan kendala biaya (cost barrier). Data SDKI 2002-2003 menunjukkan bahwa sebagian besar (48,7 persen) masalah untuk mendapatkan pelayanan kesehatan adalah karena kendala biaya, jarak dan transportasi.

Rendahnya status kesehatan penduduk

Tabel 5 Proporsi Tempat Pengobatan Responden, 2012

\begin{tabular}{|l|c|c|}
\hline \multicolumn{1}{|c|}{ Pelayanan sakit } & Jumlah & Persen \\
\hline Diobati sendiri & 5 & 10 \\
\hline Dukun & 3 & 6 \\
\hline Medis & 42 & 84 \\
\hline Total & $\mathbf{5 0}$ & $\mathbf{1 0 0}$ \\
\hline
\end{tabular}

Sumber : Data Primer, 2012.

Tabel 5 mendeskripsikan tempat dimana keluarga mendapatkan pelayanan kesehatan apabila anggota keluarga mereka mengalami sakit. Sebanyak 84 persen mereka memilih pusat-pusat pelayanan medis (polindes, Puskesmas, Praktek Bidan/Dokter, atau Rumah Sakit) dari pada pergi ketempat dukun (non medis). Fenomena ini sekaligus juga menunjukkan tingkat kesadaran dan apresiasi masyarakat yang tinggi terhadap keberadaan institusi kesehatan di sekitar lingkungan mereka. Selanjutnya, akses mereka ke fasilitas kesehatan yang ada tidak ada hubungannya dengan jumlah anak yang dimiliki maupun tingkat pendapatan. Tabel 6 menunjukkan bahwa antara mereka yang berpendapatan tinggi dan rendah memiliki akses yang sama terhadap fasilitas yang ada. Dari 33 orang yang berpendapatan redah, 78,8 persen melakukan pengobatan anggota keluarga yang sakit ke fasilitas kesehatan yang ada di desa mereka. Hal demikian sesuai dengan hasil SDKI 2002-2003 dimana masyarakat miskin atau tidak mampu cenderung memanfaatkan 
pelayanan kesehatan di Puskesmas. Hal yang penting untuk dikritisi adalah bahwa ada perubahan mindset di masyarakat desa bahwa mereka sudah memahami betul keberadaan institusi kesehatan sehingga mereka sekarang lebih cenderung berobat ke pusat-pusat fasilitas kesehatan dari pada ke dukun atau diobati sendiri. Meskipun masih ditemui ada diantara mereka pergi berobat ke dukun akan tetapi proporsinya sangat kecil (6 persen).
Dari penjelasan tersebut maka dapat disimpulkan bahwa jumlah anak yang banyak tidak menghalangi mereka untuk mendapatkan pelayanan kesehatan modern. Barangkali hal ini berhubungan dengan banyaknya program-program kesehatan yang sangat membantu penduduk miskin untuk mendapatkan pelayanan kesehatan yang baik seperti Jampersal, Askin, Kartu Sehat dan lain sebagainya.

Tabel 6 Proporsi Responden Menurut Pendapatan dan Tempat Berobat

\begin{tabular}{|l|c|c|c|c|}
\hline \multirow{2}{*}{ Pendapatan } & \multicolumn{3}{|c|}{ Tempat Berobat } & \multirow{2}{*}{ Total } \\
\cline { 2 - 4 } & Sendiri & Dukun & Medis & \\
\hline Rendah & $4(12,1)$ & $3(9,1)$ & $26(78,8)$ & $33(100)$ \\
\hline Sedang & - & - & $10(100)$ & $10(100)$ \\
\hline Tinggi & $1(14,2)$ & - & $6(85,8)$ & $7(100)$ \\
\hline
\end{tabular}

Sumber : Data Primer, 2012.

\section{Dampak Terhadap Pendidikan}

Layaknya kesehatan, pendidikan menjadi salah satu parameter Indek Pembangunan Manusia (IPM). Dan sebagaimana diketahui bahwa menurut UNDP, IPM Indonesia mengalami penurunan dari rangking 108 pada 2009 menjadi rangking ke 124 pada 2011 yang lalu. Dan Ironisnya, dari hasil Sensus Penduduk 2010, rata-rata penduduk Indonesia lama sekolahnya hanya 6,2 tahun artinya hanya tamat Sekolah Dasar (SD). Padahal target
Grand Design Pembangunan berwawasan kependudukan sekitar 11, 8 tahun atau lulus sekolah menengah. Trend perkembangan anak putus sekolah di Indonesia juga memprihatinkan karena selalu meningkat. Menurut data resmi yang dihimpun dari 33 Kantor Komnas Perlindungan Anak (PA) di 33 provinsi, jumlah anak putus sekolah pada tahun 2007 sudah mencapai 11,7 juta jiwa. Jumlah itu pasti sudah bertambah lagi pada kondisi saat ini, mengingat jumlah orang miskin selalu 
meningkat sebagai contoh pada tahun 2006 jumlah anak putus sekolah "masih" sekitar 9,7 juta anak; namun pada tahun 2007 sudah bertambah sekitar $20 \%$ menjadi 11,7 juta jiwa. Meskipun pemerintah melalui berbagai kebijakan untuk selalu meningkatkan partisipasi sekolah fakta di lapangan tidak selalu sesuai yang diharapkan. Upaya peningkatan partisipasi sekolah menjadi permasalahan strategis bagi Indonesia untuk meningkatkan mutu kualitas sumberdaya manusia (IPM). Dari berbagai kajian banyak faktor yang menyebabkan anak putus sekolah, mulai dari diri si anak, kondisi ekonomi keluarga, pendidikan orang tua, persepsi masyarakat terhadap pendidikan dan lingkungan sosial dimana anak tinggal. Kondisi ekonomi keluarga dikaitkan dengan jumlah anak yang dimiliki keluarga menjadi faktor yang sering menyebabkan anak putus sekolah (Sulistyati, 2001; Wulandari, 2012).

Di provinsi Bengkulu angka lama sekolah relatif lebih baik dibandingkan rata-rata nasional 8,2 tahun. Meskipun tingkat kemiskinannya jauh diatas ratarata nasional yaitu 18,69 persen (Sensus Penduduk 2010). Artinya animo masyarakat untuk menyekolahkan anak relatif tinggi. Lebih jauh kebijakan para kepala daerah yang menggratiskan sumbangan pendidikan juga mampu mendorong para keluarga miskin untuk masih dapat menyekolahkan anaknya.

Tabel 7 mendeskripsikan apakah jumlah anak yang banyak berdampak pada kesulitan keluarga untuk menyekolahkan anaknya. Mengingat biaya yang dikeluarkan besar, maka jumlah anak yang banyak secara signifikan akan berdampak dengan pengeluaran biaya pendidikan yang besar pula. Keluarga dengan kondisi pendapatan terbatas dengan jumlah anak yang banyak dapat berdampak pada tingginya angka putus sekolah anak. Sebagai contoh penelitian Sulistyati (2001) dari hasil analisis bivariat menunjukkan bahwa perubahan jumlah anak berhubungan dengan persepsi perbandingan kemampuan keluarga dalam meningkatkan pendidikan anak di masa krisis ekonom.

Tabel 7 memberi informasi bahwa dari 50 keluarga, 76 persen tidak ada anak mereka yang usia sekolah mengalami putus sekolah (droup out), hanya 24 persen dari mereka yang anaknya mengalami putus sekolah. Sebagaimana disampaikan sebelumnya bahwa komitmen pemerintah Bengkulu terhadap pendidikan masih lumayan baik 
dengan pengertian bahwa rata-rata lama sekolah penduduk Bengkulu lebih tinggi dari rata-rata lama sekolah penduduk secara nasional (8,2 tahun dibanding 5,6 tahun). Selanjutnya sekolah gratis menjadi trend kampanye para kandidat kepala daerah baik bupati maupun gubernur dan dalam derajat tertentu ini cukup menjanjikan untuk mendapatkan dukungan meskipun hal ini menjadi program hampir semua kandidat. Faktanya, ketika mereka terpilih program sekolah gratis SPP (Sumbangan Pembangunan Pendidikan) ini memang direalisasikan seperti di Kota Bengkulu maupun Kabupaten Benteng dimana desa Pondok Kelapa menjadi salah satu desa di wilayah kabupaten tersebut. Lebih jauh, desa Pondok Kelapa memiliki akses yang mudah untuk menjangkau sekolah-sekolah yang ada karena terletak pinggir jalan yang menghubungkan Kabupaten Benteng dengan Kota Bengkulu dan posisinya relatif dekat dengan sekolah-sekolah yang ada. Jarak dan jarak tempuh ini menjadi faktor yang tidak kalah penting disamping faktor pendapatan keluarga sebagaimana studi yang dilakukan oleh Wulandari (2012).

Tabel 7 Proporsi Putus Sekolah Anggota Keluarga

\begin{tabular}{|c|c|c|}
\hline Putus Sekolah & Jumlah & Persen \\
\hline Ya & 12 & 24 \\
\hline Tidak & 38 & 76 \\
\hline Total & $\mathbf{5 0}$ & $\mathbf{1 0 0}$ \\
\hline
\end{tabular}

Sumber : Data Primer, 2012

Sedangkan alasan yang melatar belakangi putus sekolah anak bervariasi (lihat Tabel 8) membantu keluarga menjadi alasan dominan yaitu 33,3 persen (4 keluarga) selanjutnya karena alasan biaya sebanyak 25 persen (3 keluarga). Dari kedua alasan ini cukup jelas bahwa anak-anak mereka tidak dapat melanjutkan sekolah dikarenakan kondisi ekonomi. Studi pekerja anak yang putus sekolah di Kota Bengkulu sebagaimana dilakukan oleh Mia (2011) menjelaskan bahwa anak-anak dipaksa oleh orangtua mereka untuk bekerja dikawasan pariwisata di Kota Bengkulu guna membantu ekonomi keluarga dikarenakan kondisi ekonomi keluarga. 
Tabel 8 Proporsi Responden menurut Alasan Putus Sekolah

\begin{tabular}{|c|c|c|}
\hline \multicolumn{1}{|c|}{ Alasan } & Jumlah & \multicolumn{1}{c|}{ Persen } \\
\hline Tidak ada Biaya & 3 & 25 \\
\hline Anak tidak mau sekolah & 2 & 16,7 \\
\hline Membantu keluarga & 4 & 33,3 \\
\hline Lain & 3 & 25 \\
\hline Total & $\mathbf{1 2}$ & $\mathbf{1 0 0}$ \\
\hline
\end{tabular}

Sumber : Data Primer, 2012.

Dari penjelasan ini, cukup jelas bahwa dikarenakan kebijakan pemerintah setempat mengenai upaya meringankan beban keluarga agar anakanak mereka tetap berpartisipasi dalam meningkatkan jenjang pendidikan, maka jumlah anak dalam keluarga tidak berdampak negatif yaitu menjadi halangan bagi anak-anak untuk melanjutkan pendidikan. Justru yang dirasakan berat mereka adalah bagaimana memenuhi buku-buku cetak untuk menunjang sekolah anak-anak mereka.. Hanya 38 persen (19 keluarga) dari keluarga yang mampu memenuhi secara lengkap buku-buku cetak yang diperlukan oleh anak-anak mereka bahkan ada sekitar 6 keluarga (12 persen) yang sama sekali tidak mampu membeli satu buku cetakpun. Tentunya ini menjadi persoalan lain terkait peningkatan kemampuan dan kualitas anak. Artinya untuk sekolah mereka relatif tidak menjadi masalah tetapi untuk peningkatan kualitas anak menjadi masalah.

\section{KESIMPULAN}

Pada kajian dampak jumlah anak (fertilitas) terhadap kebutuhan dasar keluarga, secara umum bahwa keluarga menganggap anak tidak sebagai beban bagi keluarga. Pada kajian yang lebih komprehensif terhadap setiap kebutuhan dasar keluarga seperti tempat tinggal (rumah), makan, kesehatan dan pendidikan, hasil kajian menunjukkan bahwa jumlah anak tidak mempengaruhi upaya keluarga untuk memenuhi kebutuhan dasar tersebut. Realitas ini menjelaskan bahwa terkait dengan anggapan keluarga terhadap nilai anak (value of children), penelitian ini menunjukkan masih kuatnya pandangan tradisionil yang sering disampaikan oleh para ahli demografi dimana pada masyarakat tradisionil anak sering dilihat dari perspektif sosial-budaya dari pada 
ekonomi. Anak dianggap sebagai sebuah rezeki atau berkah sehingga harus disikapi dengan rasa syukur. Menurut Judith Blake (1974) mengatakan masalah ekonomi adalah masalah sekunder bukan masalah normatif. Fertilitas tidak dapat hanya diterangkan dengan menggunakan ukuran ekonomi, keuntungan dan keuangan. Nilai anak dapat diartikan sebagai koleksi bendabenda bagus yang diperoleh orang tua karena mempunyai anak. Menurut Jackson anak-anak memberikan utilities dan jasa pelayanan yang produktif bagi orang tua mereka. Dalam masyarakat yang berpenghasilan rendah anak-anak dianggap sebagai tenaga kerja dan sumber pendapatan penting bagi keluarga, selain itu anak dinilai sebagai investasi hari tua atau sebagai komoditas ekonomi yang dapat disimpan dikemudian hari. Hal tersebut merupakan hubungan positif antara penghasilan dengan nilai anak.

\section{SARAN}

1. Mengkritisi realitas tersebut dan tuntutan peningkatan sumberdaya manusia yang berkualitas sebagaimana dimandatkan oleh Grand Design Pembangunan Kualitas Manusia 2035, maka diperlukan sosialisasi kepada para PUS muda tentang pentingnya meletakkan nilai anak pada tuntutan modernisasi yaitu bahwa mempersiapan kualitas anak merupakan aset yang sangat penting untuk kehidupan anak dimasa mendatang yang penuh dengan tingkat persingan yang tinggi untuk mendapatkan pekerjaan, kesehatan dan pendidikan yang layak.

2. Meskipun jumlah anak tidak mempengaruhi upaya keluarga memenuhi kebutuhan dasar, namun realitas ini harus dikritisi terkait dengan upaya peningkatan kualitas sumberdaya manusia. Penelitian ini tidak menguji kualitas pemenuhan kebutuhan dasar akan tetapi sebatas pemenuhan minimum kebutuhan dasar bahwa anggota keluarga dapat berteduh, bisa makan sehari 3 kali, anak-anak bisa sekolah dan bisa mendapatkan pelayan kesehatan dari polindes atau puskesmas. Tetapi sejauh mana kualitasnya, penelitian ini tidak dapat memberi informasi. Hal ini penting, mengingat bahwa meskipun anak-anak mereka dapat sekolah akan tetapi hanya sedikit yang mampu memberikan fasilitas seperti buku-buku pelajaran. Lebih jauh untuk pemenuhan minimum 
kebutuhan dasar banyak mereka yang terbantu dengan program pemerintah daerah seperti sekolah gratis, raskin, BLT, askin dan lain-lain. Oleh karena itu kedepan perlu dilakukan penelitian yang lebih menitikberatkan kepada kualitas kebutuhan dasar. Hal ini penting dilakukan dalam rangka peningkatan kualitas sumberdaya ke depan untuk meningkatkan angka IPM (Indeks Pembangunan Manusia) Indonesia yang semakin menurun.

\section{DAFTAR PUSTAKA}

Adioetomo. S, Burhan, L., Yunus, N., Demografi Indonesia : Mengubah Nasib Menjadi Harapan, BKKBN dan LDUI, 2010.

Becker, Gary S., A Treatise on the Family, Harvard University Press, London.1981.

Becker. An Economic Analysis of Fertility. Dalam The Essence of B.E.C.K.E.R. Ramon Febrero dan Pedro S. Schwartz. Hoover Institution Press. University, Stanford, California.1995.

Bungin, B., Metodologi Penelitian Kuantitatif, Kencana Prenada Media Group, Jakarta, Cetakan ke 5, 2010 .
Cahyat, A., Bagaimana Kemiskinan Diukur?: Beberapa Model Penghitungan Kemiskinanan di Indonesia, CIFOR, November, 2004.

Coudouel et al. (2002), Poverty Measurement and Analysis, in the PRSP Sourcebook, World Bank, Washington D.C.

Davis, Kingsley and Judith Blake, Struktur Sosial dan Fertilitas (Social Structure and Fertility Analitical Framework), Lembaga Kependudukan UGM, Yogyakarta, 1974.

Freedman, R., "Tansition from High to Low Fertility: Chalange to Demogaphers", Population Index 31, Oktober 1965.

Gillis, A.R.," Urbanization and Urbanism" dalam Hagedorn, Sociology, 4th edition, John Deyell Company, Canada, 1990.

Goldscheider, C., Populasi, Modernisasi dan Struktur Sosial, Raja Wali, Jakarta, 1985.

Hagedorn, Robert, Sociology, 4th edition, John Deyell Company, Canada, 1990.

Hugo, et.al, The demographic Dimension in Indonesia Development, Oxford University Press, New York, 1987. 
Sulistyati, J., "Hubungan Perubahan Jumlah Anak dengan Persepsi Beberapa aspek Kesejahteraan Keluarga Dimasa Krisis Ekonomi ", di kelurahan Srondol Kulon, kecamatan Banyumanik, kotaSemarang. Skripsi, Universitas Diponegoro, agustus 2001.

Mantra, Ida Bagus, Demografi Umum. Pustaka Pelajar Yogyakarta. Yogyakarta, 2000.

Mia, P, “ Studi Pekerja Anak di Kawasan Pariwisata Benteng Malboro Kota Bengkulu", Skripsi, Jurusan Sosiologi, Fisip Universitas Bengkulu, 2011.

Riskesdas, Laporan Riset Dasar Kesehatan Indonesia 2010, Badan Penelitian dan Pengembangan Kesehatan Kementerian KesehatanRI, 2010.

Ritzer, G and Goodman, D.J., Teori Sosiologi Modern,edisi ke 3, Prenada Media, Jakarta, 2005.

SDKI 2007, Laporan Survey Demografi dan Kesehatan Indonesia 2007 untuk Bengkulu, BKKBN, Jakart, 2010.

Sumarno, Pentingnya Setiap Propinsi Ber-Swasembada Beras, Pusat Penelitian dan Pengembangan Pangan, Harian Sinar Tani, 1-7 Maret 2006, No. 3139.
Sunaryanto, H. Analisis Fertilitas Bengkulu, Sensus 2010, PSK Universitas Bengkulu dan BKKBN Jakarta, 2012.

Sunaryanto, H. Analisis Fertilitas Penduduk Bengkulu, SDKI 2007, PSK Universitas Bengkulu dan BKKBN Jakarta, 2011.

Suparlan, Parsudi, 1993, Kemiskinan di Perkotaan, PT. Obor Indonesia, Jakarta.

Todaro, $M$ and Stephen C. Smith, Pembangunan Ekonomi di Negara Ketiga (Economic Development in Third World), edisi kedelapan, Erlangga, Jakarta, 2009.

Wulandari, Asri. " Hubungan Aksesibilit as, Kondisi Sosial Ekonomi, dan Motivasi Orang Tua Terhadap Anak Putus Sekolah Pada Jenjang Pendidikan Dasar di Desa Sumberduren Kecamatan Tarokan", Skripsi, Jurusan Pendidikan Geografi, Fakultas Ilmu Sosial, Universitas Negeri Malang. 2012. 